\title{
Effects of morphodynamic and estuarine gradients on the demography and distribution of a sandy beach mole crab: implications for source-sink habitat dynamics
}

\author{
Eleonora Celentano ${ }^{1}$, Nicolás L. Gutiérrez ${ }^{2}$, Omar Defeo ${ }^{1, *}$ \\ ${ }^{1}$ UNDECIMAR, Facultad de Ciencias, Iguá 4225, PO Box 10773, Montevideo 11400, Uruguay \\ ${ }^{2}$ School of Aquatic and Fishery Sciences, University of Washington, Box 355020, Seattle, Washington 98195, USA
}

\begin{abstract}
Several conceptual models relating biological and morphodynamic variables have been developed in sandy beach ecology. On estuarine sandy beaches, a major environmental factor influencing macrofaunal distribution is salinity. In this setting, the concurrent role of large-scale estuarine and morphodynamic gradients in shaping demographic patterns is still uncertain. To explain largescale variations in demographic aspects of the mole crab Emerita brasiliensis, 16 Uruguayan sandy beaches distributed along the estuarine gradient generated by the Rio de la Plata were characterized in terms of beach morphology, sediment traits and salinity over a 2 yr period. Abundance (total and discriminated by reproductive and recruitment components), biomass and body size of $E$. brasiliensis significantly increased from estuarine reflective to oceanic dissipative beaches. Further, generalized models (both additive and linear) showed that salinity, mean grain size and swash width were the most important explanatory factors of spatio-temporal variations in abundance. Sexually mature individuals and megalopae were almost absent in estuarine and oceanic reflective beaches, whereas oceanic dissipative beaches showed polymodal size structures with fully represented population components, together with extended reproductive and recruitment periods. We conclude that (1) morphodynamic and estuarine gradients are inextricably linked, affecting mole crab demography; and (2) estuarine and oceanic reflective beaches operate as sink habitats where populations do not prosper, whereas oceanic dissipative beaches act as source habitats. We thus provide empirical support to the source-sink hypothesis recently developed for sandy beaches. These long-term variations in demographic processes should be complemented by connectivity studies and genetic analyses in order to gain a deeper understanding of metapopulation dynamics in sandy beaches.
\end{abstract}

KEY WORDS: Mole crab - Emerita $\cdot$ Demography $\cdot$ Salinity $\cdot$ Sandy beaches $\cdot$ Morphodynamics Generalized additive models

Resale or republication not permitted without written consent of the publisher

\section{INTRODUCTION}

Exposed sandy beaches are dynamic ecosystems inhabited by specialized biotic assemblages that are mainly structured by physical forces (McLachlan \& Brown 2006). Thus, several ecological hypotheses have been postulated to understand the influence of the environment on beach macrofauna (Defeo \& McLachlan 2005). At the community level, the Swash Exclu- sion Hypothesis (SEH: McLachlan 1990, McLachlan et al. 1995) proposes an increase in species richness from reflective (narrow and steep, with coarse sands) to dissipative (wide and flat, with fine sands) beaches (McLachlan et al. 1995). At the population level, the Habitat Harshness Hypothesis (HHH: Defeo et al. 2003) predicts that the harsh environment in reflective beaches forces organisms to invest more energy in maintenance than in reproduction and growth, result- 
ing in lower abundance, fecundity, growth and survival rates than in dissipative beaches. In agreement with $\mathrm{SEH}$ and $\mathrm{HHH}$ predictions, studies conducted worldwide have shown a consistent decrease in community (McLachlan 1990, Defeo et al. 1992, McLachlan et al. 1993, Jaramillo et al. 2000, Soares 2003, Rodil \& Lastra 2004, McLachlan \& Dorvlo 2005) and population (truly intertidal species: Nel et al. 2001, de la Huz et al. 2002, Cardoso \& Veloso 2003, Cardoso et al. 2003, Contreras et al. 2003, Celentano \& Defeo 2006, Delgado \& Defeo 2008, Thompson \& Sánchez De Bock 2009) indicators from dissipative to reflective beaches (but see Herrmann 2009).

In relation to the patterns found at the population level, it has been postulated that post-settlement processes prevent intertidal species from establishing populations on reflective beaches. Moreover, it has been hypothesized that dissipative beaches can act as 'source' habitats, whereas reflective beaches would constitute 'sink' habitats where reproduction patterns of resident species are insufficient to balance mortality. This has been called the 'source-sink hypothesis' for intertidal sandy beach populations (Defeo \& McLachlan 2005, see also Caddy \& Defeo 2003), which is a refinement of the theory that was developed to explain morphodynamic effects on beach macrofauna. Despite the above, few attempts have been made to characterize sandy beaches in a source-sink dynamic context, particularly for intertidal sandy beach species with planktonic larvae, which tend to have widespread gene flow owing to transport by coastal currents (Murray-Jones \& Ayre 1997, Sorte et al. 2001, Diehl et al. 2007).

In estuarine sandy beaches, the mixing of freshwater runoff with marine waters produces a spatial estuarine gradient that brings about different simultaneous effects in the nearshore beach environment and in the resident fauna, impacting various levels of ecological organization, from individuals and populations (reduced abundance, survival, growth and fecundity rates: Defeo \& de Álava 1995, Lercari \& Defeo 1999, Schoeman \& Richardson 2002) to communities (reduced diversity: Defeo et al. 2009 and references therein). A recent large-scale study conducted along a full gradient generated by the Río de la Plata Estuary in the southwestern Atlantic Ocean showed that (Lercari \& Defeo 2006) (1) estuarine conditions affect beach morphodynamics and shape macroscale patterns in species richness and abundance; and (2) assemblage structures are mainly determined by the degree of change in salinity ranges, which become an ecological master factor governing the distribution of sandy beach macrofauna.

Mole crabs, including various species of Emerita (Crustacea: Anomura: Hippidae), are well-adapted to live in wave-washed sandy beaches around the world (Dugan et al. 1995, Subramoniam \& Gunamalai 2003). In particular, Emerita brasiliensis is commonly found in reflective and dissipative sandy beaches along the Atlantic coast of South America, from Venezuela to Uruguay (Defeo \& Cardoso 2004, Celentano \& Defeo 2006). E. brasiliensis has a planktonic larval stage and sedentary adult benthic stage. Females incubate embryos underneath their abdomen for some weeks. Planktonic larvae are released in the intertidal zone and develop in nearshore areas for $\sim 2$ to $3 \mathrm{mo}$, passing through 5 to 8 zoeal stages (Otegui \& Soares-Gomes 2007). Intermediate larval stages increase offshore distance, and approach the coast again during later planktonic stages (Veloso \& Valentin 1993). The sedentary phase includes juveniles, which are derived from the megalopa stage that settles on to the beach, and different developmental stages leading to adulthood (Delgado \& Defeo 2006, 2008).

Preliminary observations showed that the species also inhabits estuarine beaches affected by the estuarine gradient generated by the Rio de la Plata. However, the simultaneous role of morphodynamics and estuarine gradients in modeling large-scale demographic patterns has not been assessed. Here, we describe the results of a large scale $(\sim 400 \mathrm{~km}), 2 \mathrm{yr}$ study directed to assess the concurrent effects of freshwater discharge of Rio de la Plata and beach morphodynamics on the demography of Emerita brasiliensis in 16 sandy beaches of Uruguay. We also provide evidence for identifying source and sink habitats, and discuss whether differences in quality between sinks and sources could be explained by the difference between reflective and dissipative ends of the morphodynamic gradient described for exposed sandy beaches.

\section{MATERIALS AND METHODS}

Study system. The Río de la Plata flows to the continental shelf of Uruguay and Argentina, with landward waters coming from the Paraná and the Uruguay Rivers. It is $220 \mathrm{~km}$ wide at its opening with the Atlantic Ocean, making it the widest estuary in the world (Fig. 1). The estuary presents a strong bottom salinity front located over a submerged shoal, with a wind-dominated estuarine circulation (Simionato et al. 2008). Water density is controlled by salinity, whereas changes in temperature only display horizontal gradients (Guerrero et al. 1997). Río de la Plata waters form a low salinity plume that affects the circulation, stratification and distribution of nutrients and biological species over a wide extent of the adjacent continental shelf (Möller et al. 2008). The Uruguayan coastline 
includes $320 \mathrm{~km}$ that border the estuary and $210 \mathrm{~km}$ of contiguous oceanic open shore.

Field study. The response of Emerita brasiliensis to estuarine and morphodynamic gradients was assessed in 16 microtidal (tidal range: $0.5 \mathrm{~m}$ ) sandy beaches, represented by inner and outer estuarine beaches and strictly oceanic ones (Fig. 1). Sampling sites along the main estuary axis were selected, considering whenever possible, close pairs of beaches with the same salinity range but markedly different morphodynamic features (Lercari \& Defeo 2006). These beaches were sampled bimonthly from July 1999 to April 2001. In each beach, the salinity of the surf zone, breaker height $(\mathrm{m})$, wave period (s), beach slope (\%) and beach and swash width $(\mathrm{m})$ were recorded. Beach width was measured as the distance between the base of the dunes and the lower limit of the swash zone, where water moves over the beach face after a broken wave collapses on the sand. Swash width was measured as the distance between upper and lower swash limits at sampling time. Three transects were laid perpendicular to the shoreline and spaced $8 \mathrm{~m}$ apart, with sampling units (SUs) beginning at the base of dunes and continuing at $4 \mathrm{~m}$ intervals in a seaward direction, until at least 2 consecutive SUs yielded no more mole crabs. At each SU, sand compaction was measured using a piston pocket penetrometer and sediment samples were taken to estimate grain size (following Folk
1974), sediment moisture and organic matter content. Estimates of breaker height $(H b)$, wave period $(T)$, beach slope (BS) and sand grain size (Mz) were used to calculate Dean's parameter $\Omega$ :

$$
\Omega=\frac{H b}{W S \cdot T}
$$

where $W s$ is sand fall velocity $\left(\mathrm{m} \mathrm{s}^{-1}\right)$, which is calculated from settling velocities based on grain size according to Gibbs et al. (1971). $\Omega$ is an index of beach morphodynamic state that measures how reflective or dissipative a microtidal beach is: $\Omega<2$ characterizes reflective beaches, $\Omega>5$ defines dissipative ones, and $2<\Omega<5$ describes a wide range of intermediate beach states (Defeo \& McLachlan 2005).

Biological samples were taken with a sheet metal cylinder $(27 \mathrm{~cm}$ diameter) that removed the sediment of each SU up to a depth of $40 \mathrm{~cm}$. The mole crabs that were retained after sieving through a $0.5 \mathrm{~mm}$ mesh were fixed in $5 \%$ buffered formalin; in the laboratory, mole crabs were measured to the nearest $0.01 \mathrm{~mm}$ carapace length $(\mathrm{CL})$, i.e. from the tip of the rostrum to the distal scoop of the cephalothorax, and weighed to the nearest $0.001 \mathrm{~g}$ after drying for $48 \mathrm{~h}$ at $80^{\circ} \mathrm{C}$. In order to assess variations in recruitment, megalopa was defined as a larval settling stage, with an undeveloped ocular peduncle and the presence of plumose pleopods. Reproductive population components were

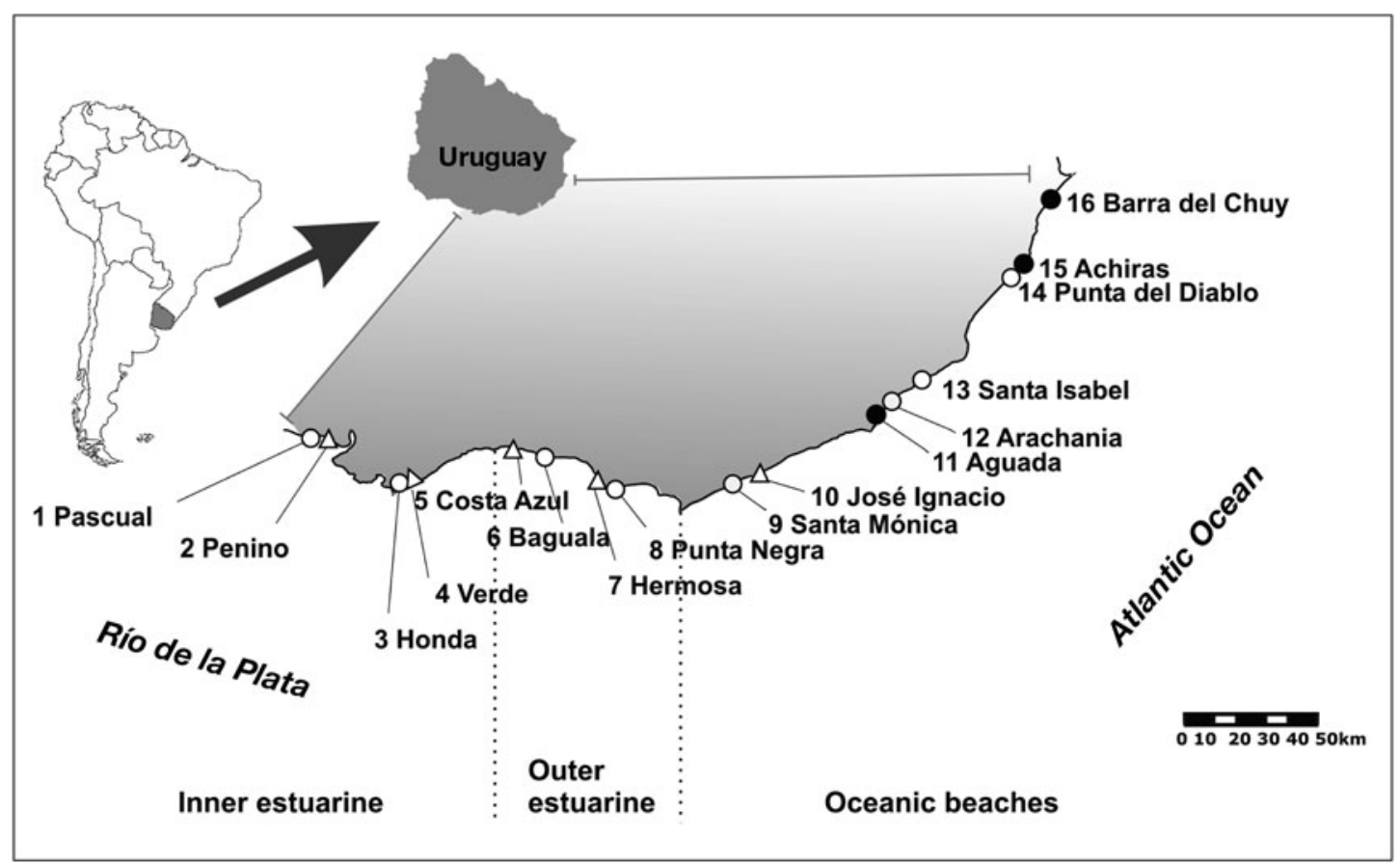

Fig. 1. Location map of 16 beaches surveyed during 2 consecutive years. Beaches are numbered from west (1: Pascual = km 0) to east (16: Barra del Chuy $=\mathrm{km} 378$ ), and categorized as reflective (O), intermediate $(\Delta)$ and dissipative ( $)$ based on mean values of Dean's parameter $\Omega$ estimates. Estuarine (inner and outer) and oceanic zones are also shown 
differentiated by sorting adults into males with and without spermatophores, and ovigerous and nonovigerous females.

Data analysis. Species abundance and biomass (total and by population component) were estimated as the number of individuals per strip transect (IST, ind. $\mathrm{m}^{-1}$ ) and biomass per strip transect (BST, $\mathrm{g} \mathrm{m}^{-1}$ ), respectively (Defeo et al. 2001). Reproductive and recruitment periods were respectively inferred from the percentage of occurrence of reproductive (ovigerous females and males with spermatophores) and recruitment (megalopae) components in the total number of sampling events on each beach $(n=11)$. Length frequency distributions (LFDs) discriminated by sex were grouped into $1 \mathrm{~mm}$ size classes. An index of recurrence of size classes (IRSC) was developed by modifying the index of recruitment recurrence provided by Caddy \& Defeo (2003) as follows:

$$
\operatorname{IRSC}=\frac{N_{L}}{N T_{L}}
$$

where $N$ defines the number of $L$ size classes in a given month and NT is the total number of size classes of Emerita brasiliensis observed in all Uruguayan beaches. IRSC ranges between 0 and 1 (all size classes present). A mean estimate of IRSC was obtained by averaging monthly estimates, whereas a global IRSC estimate $\left(\mathrm{IRSC}_{\mathrm{g}}\right.$ ) for each beach was obtained as the ratio between the number of size classes that occurred during the whole period and $N T_{L}$.

Estimates of individual physico-chemical variables and $\Omega$ were used to model spatial variations in mole crab population attributes. All variables were averaged over the entire sampling period in order to reflect a smoothed spatial trend and, at the same time, retain information from the intensive temporal coverage. Generalized linear models (GLM) and generalized additive models (GAM) (Hastie \& Tibshirani 1990, Guisan \& Thuiller 2005) were also used to examine the relationship between mole crab abundance and environmental variables, considering for this purpose all the information gathered in the 11 sampling dates for the 16 beaches. Due to overdispersion in the abundance data, negative binomial models were used for both GLMs and GAMs; in addition, thin plate splines were used based on its optimality properties and suitability for relatively small data sets (Wood 2006). GAMs fit nonparametric functions to estimate the relationships between response and predictor variables without imposing limitations on the form of the underlying relationships. Smoothing parameters, as well as the degrees of freedom (the degree of nonlinearity) of the functions from the data, were estimated using the generalized cross-validation (GCV) criterion. An explanatory variable or term in the model was removed (as per Wood 2006) if (1) the estimated degrees of freedom (edf) for the term were close to $1 ;$ (2) the plotted confidence band for the term included 0 everywhere; and (3) the GCV score decreased and the deviance explained increased when the term was dropped. Because of potential correlations among covariates, terms were dropped one at a time starting with the term for which the 0 line was most within the confidence band, which means that the estimated nonlinear part of the trend is relatively flat (Wood 2006). Moreover, colinearity was checked using the variance inflation factor (VIF: Montgomery \& Peck 1992). VIF values were always $<5$, indicating that none of the variables were candidates for elimination. Each model fit was analyzed with respect to the level of deviance explained ( 0 to $100 \%$; the higher the better), the GCV score (the lower the better) and the confidence region for the smooth (which should not include 0s throughout the range of the predictor). The Akaike's information criterion (AIC) was also used to evaluate each model fit and parsimony (Chambers \& Hastie 1992). The AIC was calculated in $\mathrm{R}$ (http://cran.r-project.org/) as -2 log likelihood +2 npar, where npar represents the number of parameters in the fitted model. Residual plots were evaluated for violations of model assumptions. In order to assess whether the nonparametric smooth terms should be simplified to linear terms, negative binomial GLMs were built using the same variables that were selected by GAMs. Both approaches were then compared using AIC, and significant differences in deviance were checked using approximate $\chi^{2}$ tests (Hastie \& Tibshirani 1990). All models were estimated using the GAM function in the mgcv and MASS libraries of $\mathrm{R}$.

\section{RESULTS}

The large-scale environmental characterization of the 16 sandy beaches studied is shown in Fig. 2. Mean salinity increased from west to east, ranging from 4.4 (Beach 2) to 29.2 (Beach 16). Morphodynamic states of oceanic beaches ranged from dissipative (Beaches 11, 15 and 16) to intermediate-reflective (Beaches 9, 12 and 13), while inner and outer estuarine beaches were mostly intermediate-reflective (Fig. 2a). The mean value of Dean's parameter $\Omega$ was lowest at Beach 3 (1.3) and highest at Beach 16 (6.3). Slope and grain size did not follow any evident spatial trend (Fig. 2b); the outer estuarine and reflective Punta Negra (Beach 8) was the narrowest and steepest beach with the coarsest sediments $(37 \mathrm{~m}, 8.82 \%$ and $0.64 \mathrm{~mm}$, respectively). By contrast, Penino (Beach 2: inner estuarine) was the widest and flattest beach with the narrowest swash zone and the highest sediment water content 

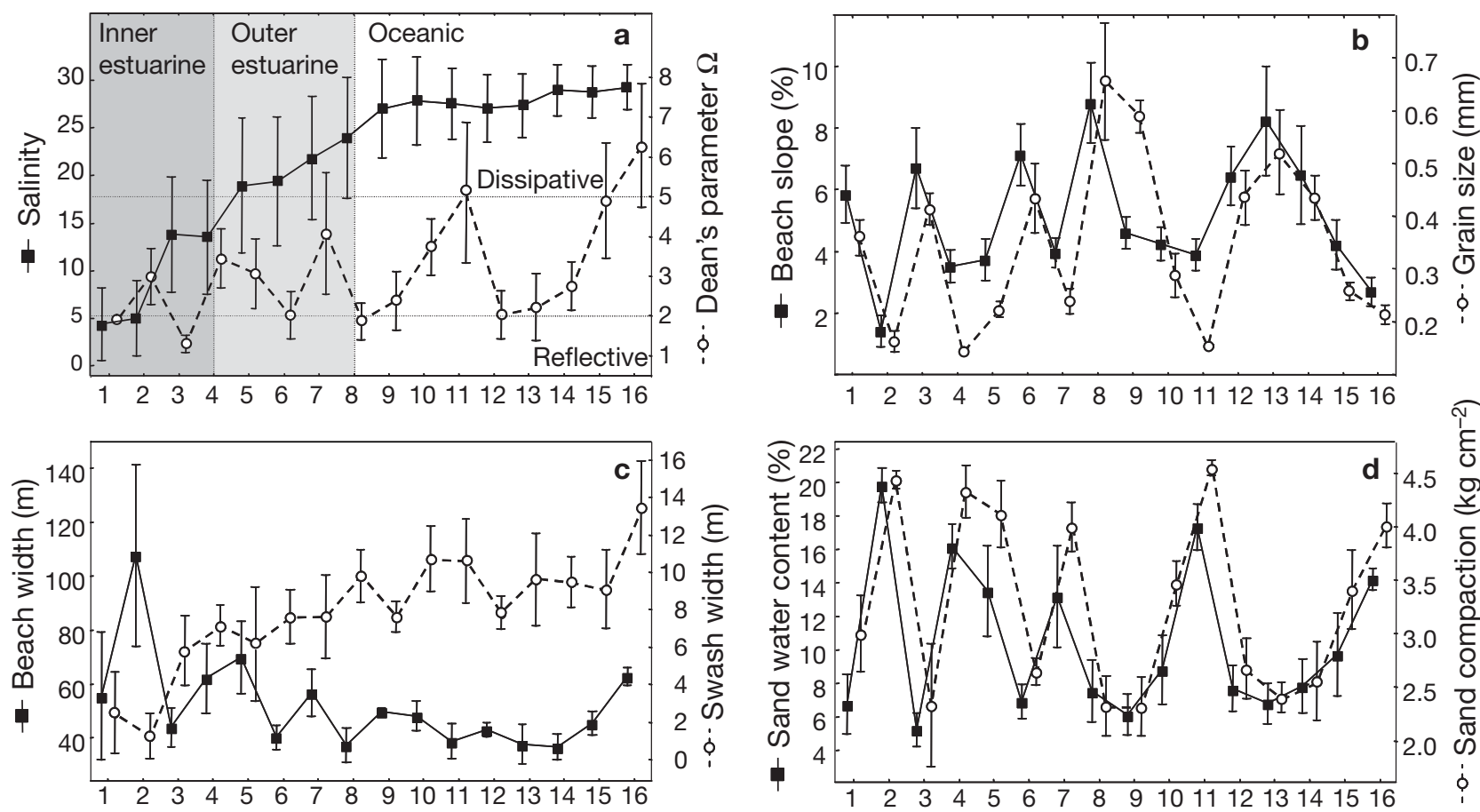

Beach no.

Fig. 2. Large-scale distribution of selected abiotic variables on 16 Uruguayan sandy beaches: mean $\pm 95 \%$ CI of (a) salinity and Dean's parameter; (b) slope and grain size; (c) beach and swash width; and (d) sand water content and compaction. In (a), the classification of beaches according to morphodynamics and salinity is highlighted. Beaches are numbered following Fig. 1. Note the artificial scale on the $x$-axis

(108 $\mathrm{m}, 1.42 \%, 1 \mathrm{~m}$ and $20 \%$, respectively), behaving as a tidal flat (Fig. $2 b-d$ ). The widest swash zone was found in the easternmost oceanic dissipative Barra del Chuy beach $(13 \mathrm{~m})$.

The mean abundance and biomass of Emerita brasiliensis (total and by population component) significantly increased from reflective to dissipative beaches and from estuarine to oceanic ones (Figs. $3 \& 4$, Table 1). Thus, mean total mole crab abundance was significantly $(p<0.001)$ related to individual abiotic variables and $\Omega$ through linear and nonlinear functions, while mean total biomass was significantly related to abiotic variables or $\Omega$ only through nonlinear models (Fig. 3, Table 1).

GAM results showed that salinity, swash width and grain size were the best significant predictors $(\mathrm{p}<$ 0.001) of large-scale variation in the abundance of Emerita brasiliensis, as evidenced by the consistent increase in $\mathrm{r}^{2}$ and deviance explained, concurrent with a decrease in the GCV score and AIC between GAMs (Table 2). Mole crab abundance showed a nonlinear positive relationship with salinity and swash width and a negative relationship with mean grain size (Fig. 5). Among these 3 variables, the strongest GAM relationship occurred between mole crab abundance and salinity, which explained $32 \%$ of the model deviance.
The GAM clearly achieved lower AIC and decreases in the residual deviance of $26.09\left(\mathrm{p}\left(\chi^{2}\right)<0.001\right)$ and $12.35 \%\left(\mathrm{p}\left(\chi^{2}\right)=0.008\right)$ when compared with linear and quadratic GLMs, respectively. Thus, the flexibility offered by GAMs significantly improved the quality of the fits.

Reproductive population components (ovigerous females and males with spermatophores) of Emerita brasiliensis were almost absent in inner and outer estuarine beaches throughout the $2 \mathrm{yr}$ period. In oceanic beaches, they consistently increased in abundance and biomass from reflective to dissipative systems. Ovigerous females were absent in the oceanic intermediate/ reflective Beaches 9,12 and 13 (Fig. 4a,b). Recruitment (megalopae abundance and biomass) also exponentially increased with $\Omega$ (Table 1, Fig. 4e). These overall patterns for reproductive and recruitment components were reflected in significant $(p<0.001)$ relationships between abundance and environmental variables, notably $\Omega$ and swash width (Table 1, Fig. 4a,c,e). Moreover, the occurrence of ovigerous females, males with spermatophores and megalopae exponentially increased with $\Omega$ and salinity, consistently indicating more extended reproductive and recruitment seasons towards oceanic dissipative beaches (Table 1, Fig. $4 \mathrm{~b}, \mathrm{~d}, \mathrm{f})$. 

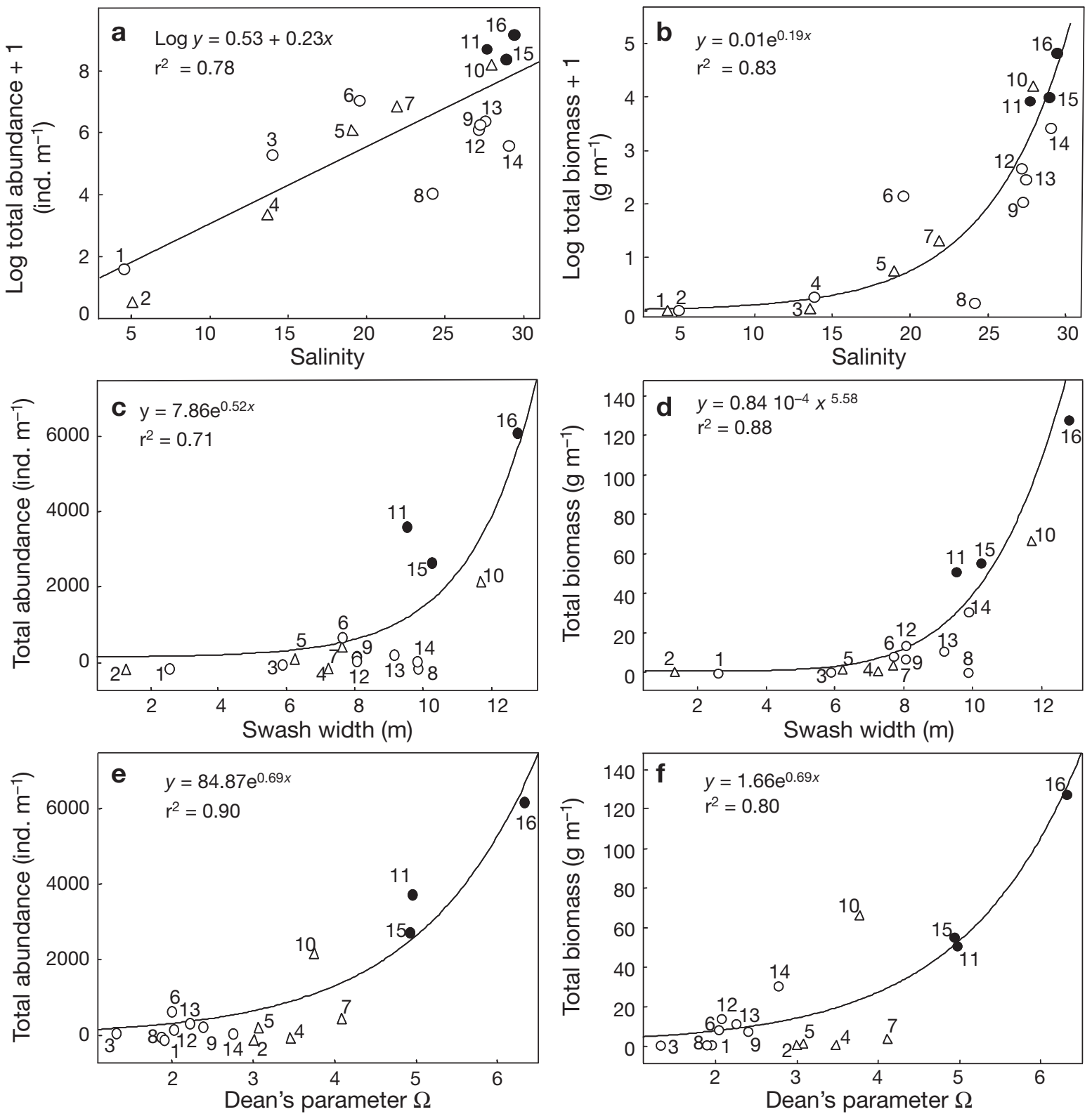

Fig. 3. Emerita brasiliensis. Best models ( $<0.001)$ fitted for the relationships between mean total abundance (left panels) or biomass (right panels) and environmental variables or Dean's parameter $\Omega$. Beaches are numbered and categorized as reflective $(\bigcirc)$, intermediate $(\Delta)$ and dissipative $(\bullet)$, following Fig. 1

Analysis of LFDs and the concurrent determination of IRSC discriminated by sex showed that the representation of Emerita brasiliensis size classes markedly increased from estuarine reflective to oceanic dissipative beaches (Figs. $6 \&$ 7). Mole crabs did not occur at the westernmost inner estuarine Beaches 1 and 2 (only 1 megalopa in the former), whereas inner and outer estuarine Beaches 3 to 9 had few size classes (very low IRSC $_{g}$ values) represented by small individuals that did not become actively reproductive adults. $\mathrm{IRSC}_{\mathrm{g}}$ increased towards oceanic beaches, with 2 dissimilar patterns (Fig. 6): (1) reflective Beaches 12, 13 and 14 presented a higher relative representation of larger mole crab size classes than estuarine beaches $(0.52<$ IRSC $_{g}<0.77$ ); and (2) dissipative Beaches 11, 15 and 16 showed polymodal size structures with fully represented population components (including larger females that were virtually absent in reflective beaches), which yielded the highest IRSCg values. Consequently, the IRSC was significantly related to swash width, $\Omega$ and salinity range through exponential models (Table 3, Fig. 7). Following the same pattern, the 

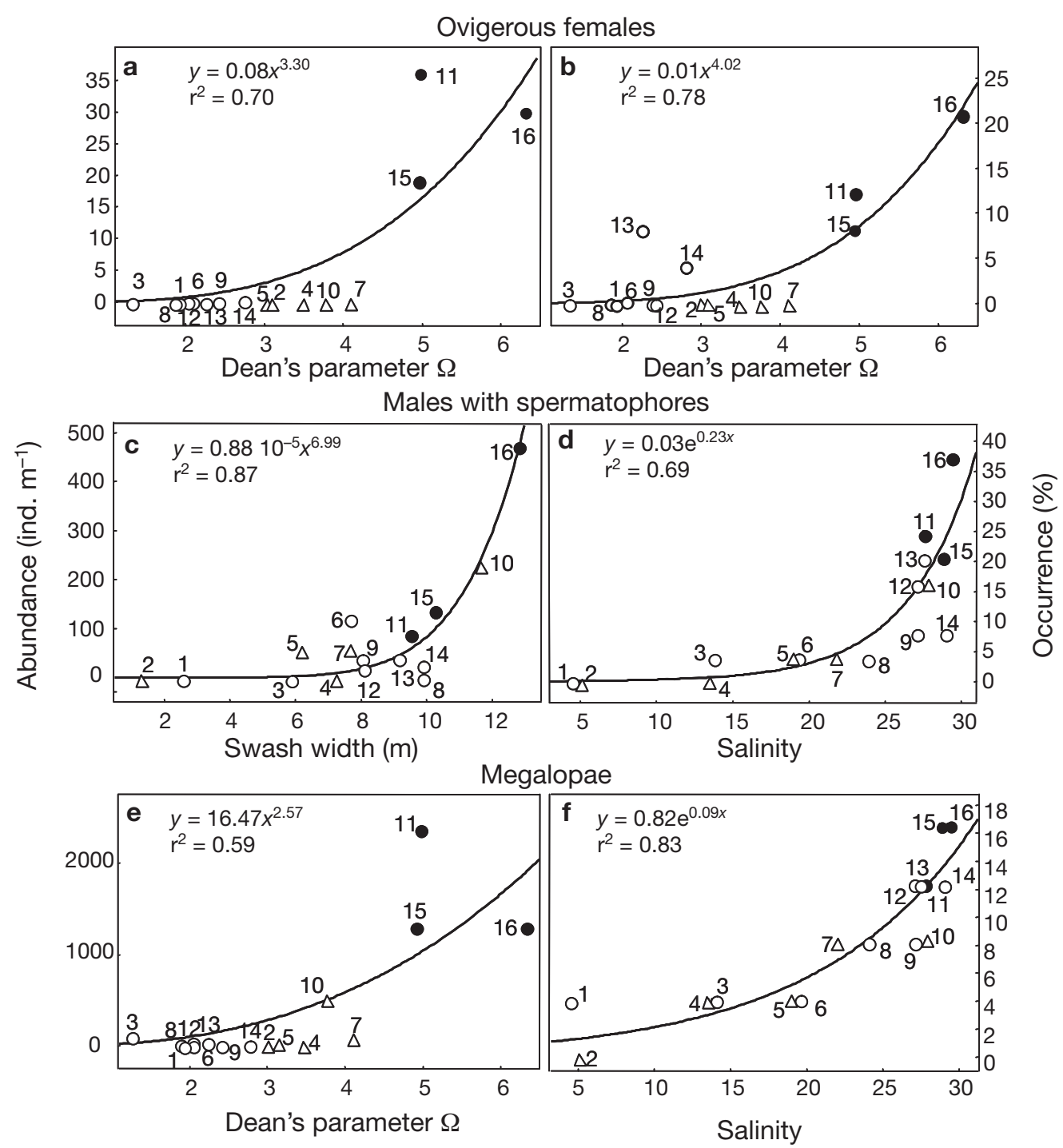

Fig. 4. Emerita brasiliensis. Best models ( $<$ 0.001) fitted between $(\mathrm{a}, \mathrm{c}, \mathrm{e})$ mean abundance and $(\mathrm{b}, \mathrm{d}, \mathrm{f})$ occurrence of reproductive (ovigerous females $[\mathrm{a}, \mathrm{b}]$ and males with spermatophores $[\mathrm{c}, \mathrm{d}]$ ) or recruitment (megalopae [e,f]) population components and environmental variables or Dean's parameter $\Omega$. Beaches are numbered and categorized as reflective $(0)$, intermediate $(\Delta)$ and dissipative $(\bullet)$, following Fig. 1. Note the different $y$-axis scales

largest males and females of E. brasiliensis significantly increased from estuarine to oceanic beaches and, to a lesser extent, from reflective to dissipative ones, maximum carapace length thus being exponentially related to salinity and swash width (Fig. 8, Table 3).

\section{DISCUSSION}

This 2 yr large-scale study showed an increase in the abundance (total and discriminated by reproductive and recruitment components), biomass and body size of the mole crab Emerita brasiliensis from estuarine reflective to oceanic dissipative beaches. Thus, the inter- action between morphodynamic (e.g. swash features, mean grain size and wave height) and estuarine (e.g. salinity) gradients affected a broad spectrum of ecological processes. The spatial variations in abundance largely reflected the extent to which local sandy beaches satisfy niche requirements of the mole crab. In particular, swash features characterize the active living zone of $E$. brasiliensis in the beach and, together with sediment characteristics, affected its distribution patterns at a local scale, providing strong support for the HHH. Thus, the large-scale distribution of the mole crab could be seen as a mosaic of local beaches characterized by a set of environmental variables across the morphodynamic and estuarine gradients, which modulate local demographic variations. 
Table 1. Emerita brasiliensis. Best linear and nonlinear models $(p<0.001)$ estimated between population features and abiotic variables. $\Omega$ : Dean's parameter; SW: swash width (m). All models are $y=a \mathrm{e}^{b x}$, unless denoted by ${ }^{*} \log y+1=a+b x$, ${ }^{* *} y=a x^{b}$ or ${ }^{* * *} \log y+1=a \mathrm{e}^{b x}$

\begin{tabular}{|c|c|c|c|c|}
\hline & $\begin{array}{c}\text { Abiotic } \\
\text { variable }\end{array}$ & $a(\mathrm{SE})$ & $b(\mathrm{SE})$ & $r^{2}$ \\
\hline \multicolumn{5}{|l|}{ Abundance (ind. $\mathrm{m}^{-1}$ ) } \\
\hline \multirow[t]{3}{*}{ Total } & $\Omega$ & $84.87(41.90)$ & $0.69(0.08)$ & 0.90 \\
\hline & SW & $7.86(10.64)$ & $0.52(0.11)$ & 0.71 \\
\hline & Salinity $^{*}$ & $0.53(1.19)$ & $0.23(0.05)$ & 0.78 \\
\hline \multirow[t]{2}{*}{ Females } & SW & $0.35(0.37)$ & $0.69(0.08)$ & 0.91 \\
\hline & Salinity** & $* * \quad 3.95 \times 10^{-62}(0.00)$ & $5.11(2.02)$ & 0.65 \\
\hline Ovigerous females & $\Omega^{* *}$ & $0.08(0.12)$ & $3.30(0.85)$ & 0.70 \\
\hline \multirow[t]{2}{*}{ Males } & $\Omega$ & $14.40(8.49)$ & $0.81(0.98)$ & 0.89 \\
\hline & Salinity & $1.18 \times 10^{-65}(0.00)$ & $5.38(2.48)$ & 0.54 \\
\hline \multirow[t]{3}{*}{ Males w/spermatophores } & $\mathrm{SW}^{* *}$ & $0.88 \times 10^{-5}\left(2.2 \times 10^{-5}\right)$ & $6.99(1.01)$ & 0.87 \\
\hline & $\Omega$ & $3.92(3.01)$ & $0.75(0.13)$ & 0.78 \\
\hline & Salinity & $1.23 \times 10^{-12}(0.00)$ & $1.14(0.52)$ & 0.48 \\
\hline Megalopae & $\Omega^{* *}$ & $16.47(22.01)$ & $2.57(0.79)$ & 0.59 \\
\hline \multicolumn{5}{|l|}{ Biomass $\left(\mathrm{g} \mathrm{m}^{-1}\right)$} \\
\hline \multirow[t]{3}{*}{ Total } & $\mathrm{SW}^{* *}$ & $8.44 \times 10^{-5}\left(1.57 \times 10^{-4}\right)$ & $5.58(0.74)$ & 0.88 \\
\hline & Salinity** & $* * \quad 0.01(0.02)$ & $0.19(0.04)$ & 0.83 \\
\hline & $\Omega$ & $1.66(1.06)$ & $0.69(0.11)$ & 0.80 \\
\hline \multirow[t]{3}{*}{ Females } & SW & $0.10(0.09)$ & $0.53(0.07)$ & 0.85 \\
\hline & $\Omega$ & $0.97(0.59)$ & $0.72(0.10)$ & 0.84 \\
\hline & Salinity & $7.12 \times 10^{-10}(0.00)$ & $0.86(0.23)$ & 0.77 \\
\hline \multirow[t]{3}{*}{ Males } & $\mathrm{SW}^{* *}$ & $3.01 \times 10^{-5}\left(7.27 \times 10^{-5}\right)$ & $5.36(0.98)$ & 0.80 \\
\hline & $\Omega$ & $0.64(0.65)$ & $0.54(0.18)$ & 0.42 \\
\hline & Salinity & $1.67 \times 10^{-4}\left(1.24 \times 10^{-3}\right)$ & $0.38(0.26)$ & 0.41 \\
\hline \multirow[t]{2}{*}{ Males w/spermatophores } & $\mathrm{SW}^{* *}$ & $4.35 \times 10^{-5}\left(1.36 \times 10^{-4}\right)$ & $4.70(0.93)$ & 0.74 \\
\hline & Salinity & $4.98 \times 10^{-5}\left(3.36 \times 10^{-4}\right)$ & $0.38(0.23)$ & 0.45 \\
\hline Megalopae & $\Omega^{* *}$ & $0.04(0.05)$ & $2.45(0.74)$ & 0.60 \\
\hline \multicolumn{5}{|l|}{ Occurrence (\%) } \\
\hline \multirow[t]{2}{*}{ Ovigerous females } & $\Omega^{* *}$ & $1.31 \times 10^{-2}\left(1.95 \times 10^{-2}\right)$ & $4.02(0.83)$ & 0.78 \\
\hline & Salinity & $9.05 \times 10^{-11}(0.00)$ & $0.88(0.36)$ & 0.58 \\
\hline \multirow[t]{3}{*}{ Males w/spermatophores } & Salinity & $3.03 \times 10^{-2}\left(7.4 \times 10^{-2}\right)$ & $0.23(0.08)$ & 0.69 \\
\hline & $\mathrm{SW}^{* *}$ & $4.26 \times 10^{-3}\left(7.03 \times 10^{-3}\right)$ & $0.29(0.06)$ & 0.65 \\
\hline & $\Omega$ & $0.47(0.24)$ & $0.46(0.09)$ & 0.59 \\
\hline Megalopae & Salinity & $0.82(0.42)$ & $0.09(0.02)$ & 0.83 \\
\hline
\end{tabular}

The GAM built here was useful to model mole crab-habitat relationships. Better fits obtained with GAM when compared to those obtained with linear and quadratic GLMs (Table 2) are based on the rationale that the response of mole crab abundance along environmental predictors is neither linear nor monotonic. Hence, this more flexible framework resulted in more realistic and informative models. Many of the relationships between environmental features and mole crab abundance were nonlinear (Table 1). The most parsimonious GAM included swash width, mean grain size and salinity: the first 2 variables reflect the quality of the habitat at a mesoscale (i.e. individual beaches, see Defeo \& McLachlan 2005 for concept development), while salinity represents the influence of the macroscale estuarine gradient.

The multi-site 2 yr analysis showed that mole crabs either did not occur in estuarine beaches (Beaches 1 and 2) or occurred there sporadically (from Beaches 3 to 8). Indeed, the LFDs of mole crabs in the latter were represented by small individuals $(<10 \mathrm{~mm}$ CL, see Fig. 6) that recruited in summer months, concurrent with the (1) intrusion of salty and warm waters of the tropical Brazil Current during its southward flow in this season; and (2) lowest levels of freshwater discharge by Paraná and Uruguay Rivers that generate a minor influence of the estuarine gradient by the Río de la

Table 2. Emerita brasiliensis. Model selection (generalized linear model, GLM and generalized additive model, GAM) for mole crab abundance (ind. $\mathrm{m}^{-1}$ ). Terms that were not significant $(\mathrm{p}>0.05)$ were dropped from the model. Percent of deviance explained, adjusted $\mathrm{r}^{2}$, generalized cross-validation score (GCV) and Akaike information criterion (AIC) are given. s: use of splines; edf: estimated degrees of freedom; S: salinity; Mz: mean grain size $(\mathrm{mm})$; SW: swash width $(\mathrm{m})$; BS: beach slope (\%). The best model is highlighted in bold italics. Note: As each term is added for GAMs, explained deviance, $\mathrm{r}^{2}$, GCV score and AIC were examined to determine whether the term would be included in the final model (numbers in bold italics). Linear and quadratic GLMs were also fitted for comparison purposes, using the variables selected by the best GAM fit. Only the most relevant GAM fits were included

\begin{tabular}{|c|c|c|c|c|c|c|}
\hline Model & Terms & edf & $\begin{array}{c}\text { Deviance } \\
\text { explained (\%) }\end{array}$ & $\mathrm{r}^{2}$ & GCV & AIC \\
\hline GLM Linear & Abundance $\sim \mathrm{S}+\mathrm{Mz}+\mathrm{SW}$ & & & 0.15 & & 599 \\
\hline GLM Quadratic & Abundance $\sim \mathrm{S}+(\mathrm{S})^{2}+\mathrm{Mz}+(\mathrm{Mz})^{2}+\mathrm{SW}+(\mathrm{SW})^{2}$ & & & 0.26 & & 593 \\
\hline GAM & Abundance $\sim \mathrm{s}(\mathrm{S})$ & 4.11 & 31.9 & 0.27 & 1.04 & 592 \\
\hline GAM & Abundance $\sim \mathrm{s}(\mathrm{S})+\mathrm{s}(\mathrm{Mz})$ & 6.64 & 37.9 & 0.36 & 1.04 & 580 \\
\hline GAM & Abundance $\sim \mathrm{s}(\mathrm{S})+\mathrm{s}(\mathrm{Mz})+\mathrm{s}(\mathrm{SW})+\mathrm{s}(\mathrm{BS})$ & 9.34 & 40.7 & 0.30 & 1.06 & 579 \\
\hline GAM & Abundance $\sim s(S)+s(M z)+s(S W)$ & 8.33 & 41.2 & 0.36 & 1.03 & 576 \\
\hline
\end{tabular}



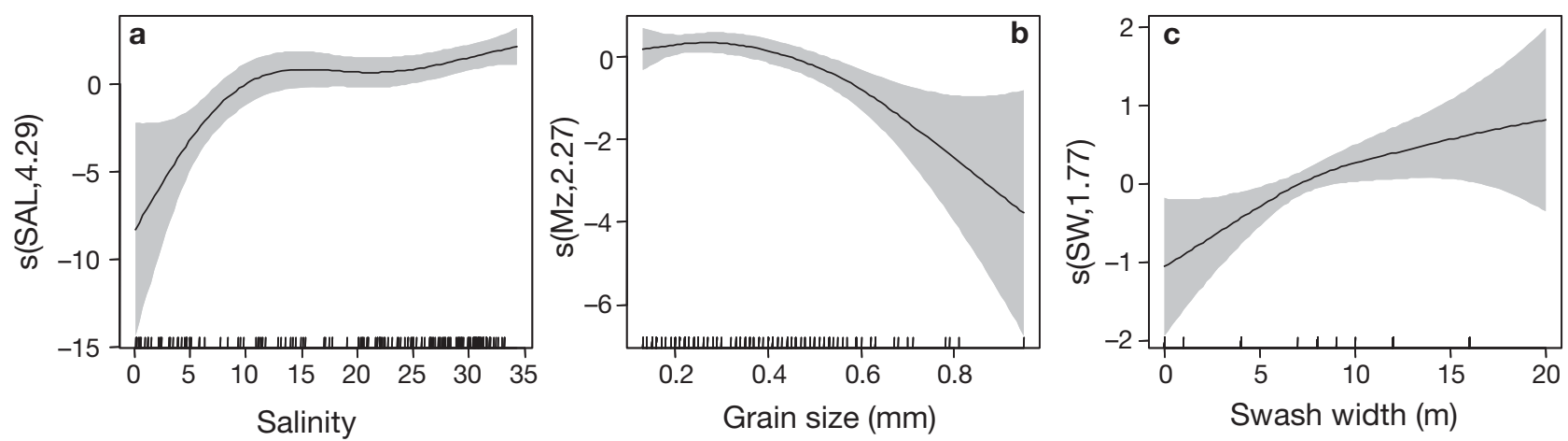

Fig. 5. Results of the generalized additive model (GAM) procedure showing the relationship (solid line) between Emerita brasiliensis abundance and each meaningful environmental predictor: (a) salinity (SAL), (b) mean grain size (Mz) and (c) swash width (SW). Shaded areas indicate 2SE above and below the estimate of the smooth curve. The 'rug plots' on the $x$-axis indicate the range of variables over which measurements were taken. Numbers after the variable name on the $y$-axis represent estimated degrees of freedom (edf). s: use of splines

Estuarine

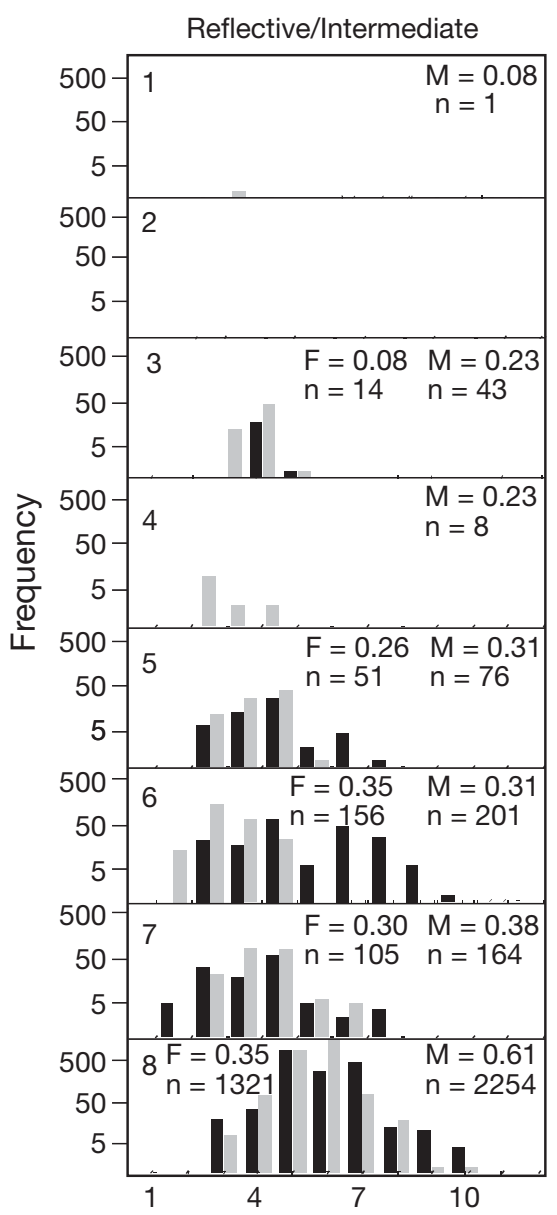

Oceanic

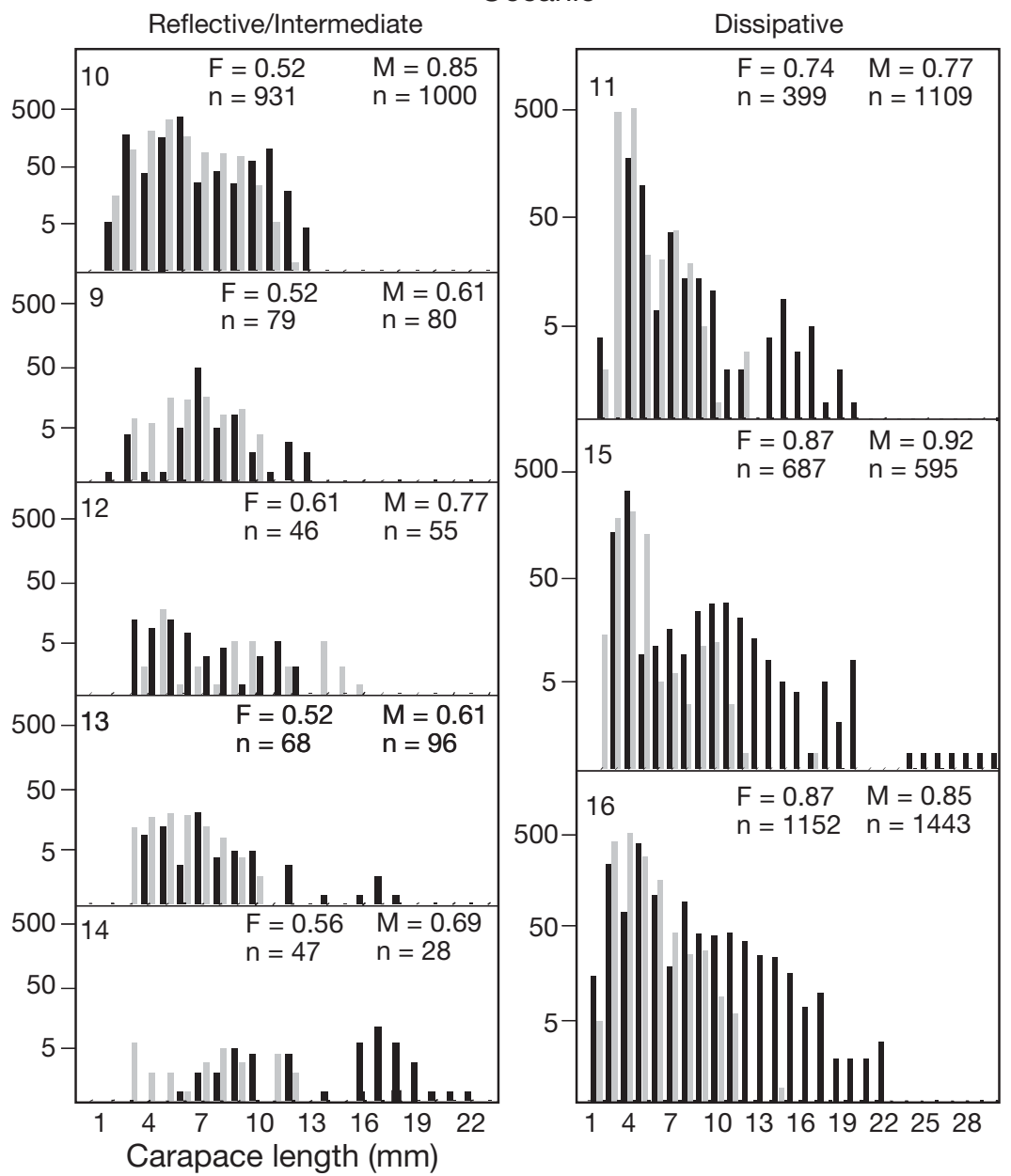

Fig. 6. Emerita brasiliensis. Length-frequency distributions (combined for whole study) discriminated by beach and sex (black: females; gray: males). M, F: global index of recurrence of size classes (IRSCg) for females and males, respectively. No mole crabs were collected in Penino beach. Numbers at top and left-hand side of panels: beach nos. (see Fig. 1) 

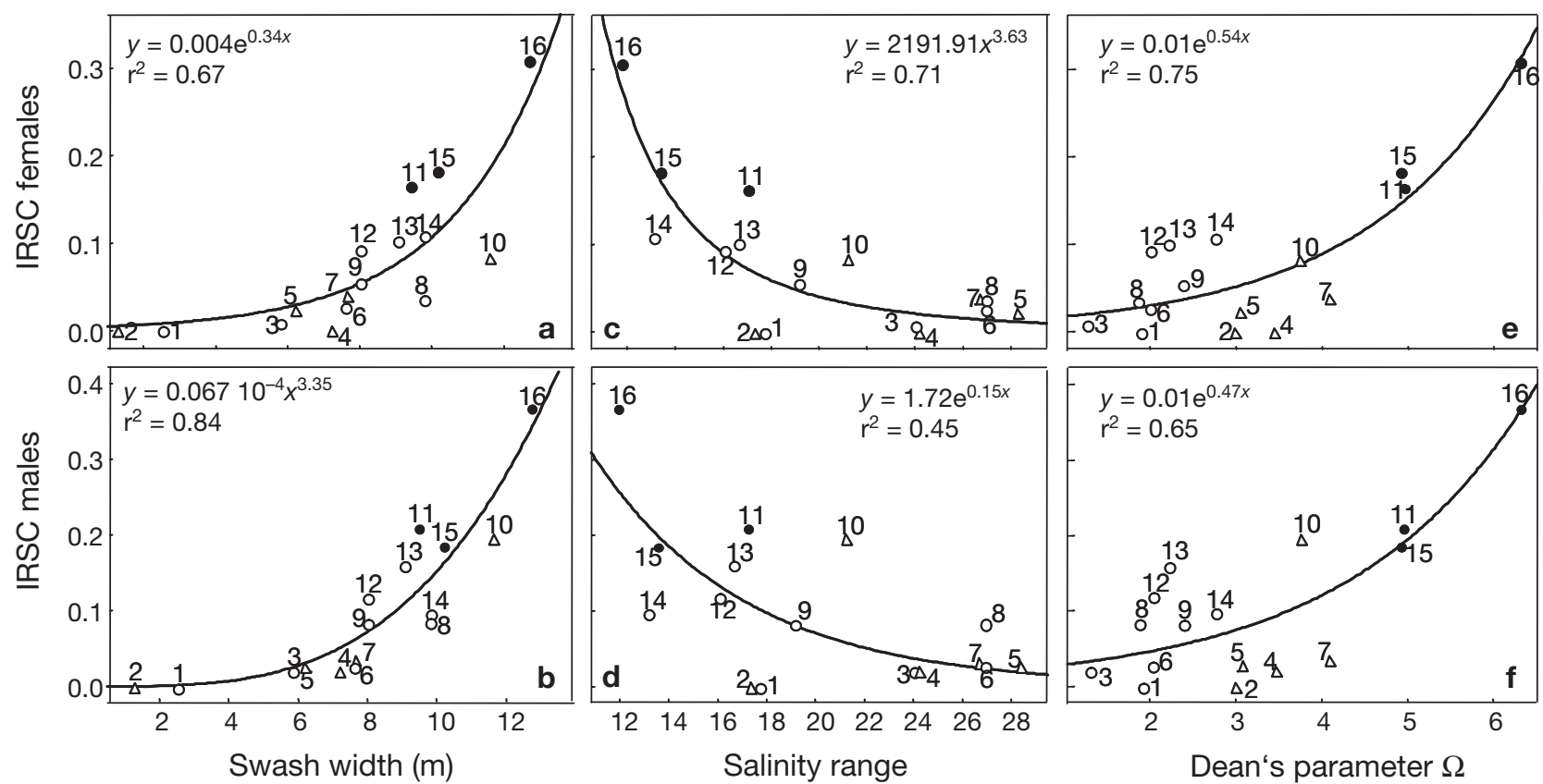

Fig. 7. Emerita brasiliensis. Best models $(\mathrm{p}<0.001)$ fitted between the mean index of recurrence of size classes (IRSC) and environmental variables or Dean's parameter $\Omega$. Beaches are numbered and categorized as reflective $(0)$, intermediate $(\Delta)$ and dissipative (•), following Fig. 1

Table 3. Emerita brasiliensis. Best nonlinear models $(\mathrm{p}<0.001)$ estimated between the index of recurrence of size classes (IRSC) and abiotic variables. $\Omega$ : Dean's parameter; SW: swash width $(\mathrm{m})$. All models are $y=a \mathrm{e}^{b x}$, unless denoted

$$
\text { by }{ }^{*} y=a x^{b}
$$

\begin{tabular}{|c|c|c|c|c|}
\hline & Abiotic variable & $a(\mathrm{SE})$ & $b(\mathrm{SE})$ & $r^{2}$ \\
\hline \multicolumn{5}{|l|}{ IRSC } \\
\hline \multirow[t]{4}{*}{ Females } & Salinity & $4.01 \times 10^{-2}(0.00)$ & $0.46(0.13)$ & 0.75 \\
\hline & $\Omega$ & $0.01\left(6.8 \times 10^{-3}\right)$ & $0.53(0.09)$ & 0.75 \\
\hline & Salinity range ${ }^{*}$ & $2191.91(4420.24)$ & $-3.63(0.77)$ & 0.71 \\
\hline & $\mathrm{SW}^{*}$ & $4.44 \times 10^{-3}\left(0.11 \times 10^{-5}\right)$ & $0.34(0.07)$ & 0.67 \\
\hline \multirow[t]{4}{*}{ Males } & $\mathrm{SW}^{*}$ & $6.73 \times 10^{-5}\left(8.03 \times 10^{-5}\right)$ & $3.35(0.49)$ & 0.84 \\
\hline & Salinity & $4.93 \times 10^{-4}\left(7.57 \times 10^{-4}\right)$ & $0.20(0.05)$ & 0.82 \\
\hline & $\Omega$ & $1.77 \times 10^{-2}\left(8.55 \times 10^{-5}\right)$ & $0.47(0.09)$ & 0.65 \\
\hline & Salinity range & $1.72(0.42)$ & $-0.15(0.05)$ & 0.45 \\
\hline \multicolumn{5}{|c|}{ Maximum carapace length (mm) } \\
\hline \multirow[t]{2}{*}{ Females } & Salinity & $0.69(0.34)$ & $0.12(0.01)$ & 0.92 \\
\hline & $\mathrm{SW}^{*}$ & $0.53(0.58)$ & $1.56(0.47)$ & 0.61 \\
\hline \multirow[t]{2}{*}{ Males } & Salinity & $1.85(0.50)$ & $0.07(0.01)$ & 0.88 \\
\hline & $\mathrm{SW}^{*}$ & $0.99(0.53)$ & $1.08(0.24)$ & 0.77 \\
\hline
\end{tabular}

to 14) throughout the study period. In contrast, dissipative beaches were characterized by a higher abundance of these population components, and the presence of all potential size classes (e.g. Beaches 11, 15 and 16), as reflected in high IRSC values.

The increasing abundance of these population components from estuarine to oceanic beaches (estuarine gradient), and from reflective to dissipative beaches (morphodynamic gradient) favors the recognition of dissipative oceanic beaches as source habitats, whereas estuarine and reflective beaches constitute sink habitats whose within-beach reproduction pattern could be insufficient to balance mortality. These statements are supported by other multi-year studies: (1) Defeo et al.

Plata (Ortega \& Martínez 2007). No adults were ever observed in these beaches, suggesting that high postsettlement mortality rates in sedentary benthic forms may be caused by a sharp decrease in habitat quality, particularly in autumn and winter months that are characterized by low temperatures and salinities, and insufficient food (Lercari \& Defeo 2006). Following the same trend as in estuarine beaches, reproductive and recruitment population components were practically absent in oceanic reflective beaches (e.g. Beaches 12
(2001) found a few $(<5)$ ovigerous females in the reflective Arachania (Beach 12 in this study), and only in 1 of the 22 mo sampled between 1996 and 1997, whereas the dissipative Barra del Chuy (Beach 16) population presented a high abundance of ovigerous females in 8 mo, as well as higher female growth rates, fecundity, egg production potential, size at maturity and individual weight than in the reflective beach. (2) In an 18 mo study carried out between 2003 and 2004, Delgado \& Defeo (2008) also found similar trends in tissular and 


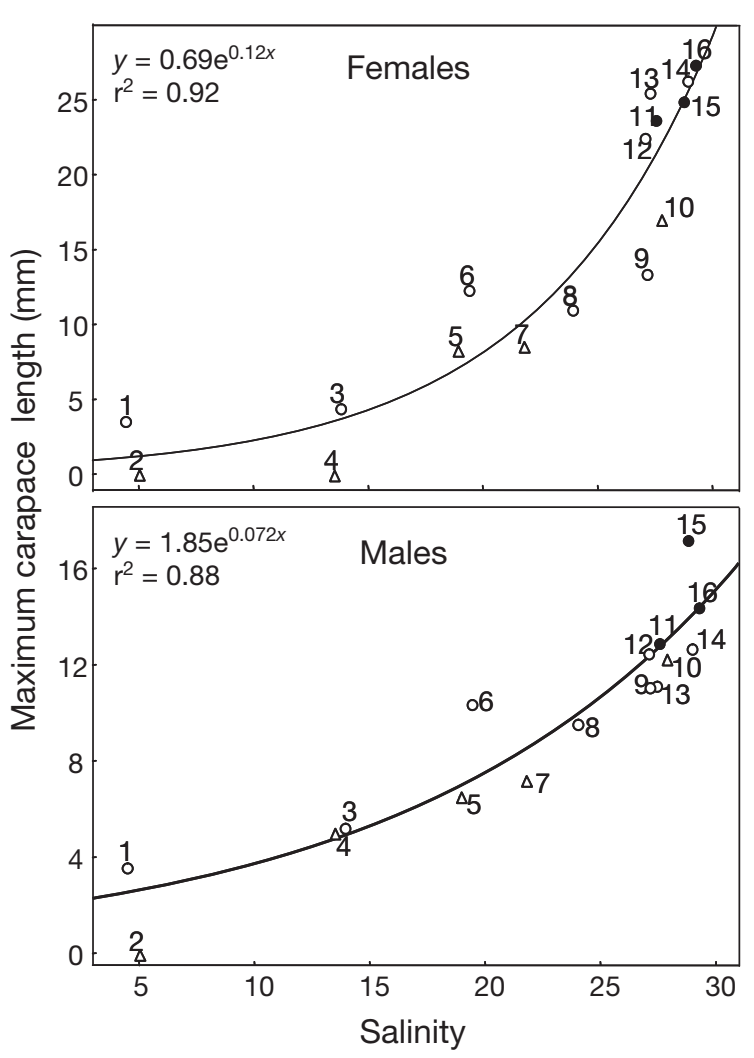

Fig. 8. Emerita brasiliensis. Best models $(p<0.001)$ fitted between salinity and largest individual lengths of females and males. Beaches are numbered and categorized as reflective $(0)$, intermediate $(\Delta)$ and dissipative $(\bullet)$, following Fig. 1

population level responses to habitat harshness: the reproductive cycle (e.g. oogenesis and female parental care) and the recruitment period were more compressed in reflective than in dissipative beaches, whereas the beginning of vitellogenesis, ovarian maturity, male sexual differentiation and the end of spermatogenesis occurred at smaller sizes under dissipative conditions.

The simple source-sink model depicted here suggests that differences between beach categories are extreme. In this sense, mole crab populations in highquality source habitats (dissipative beaches) should have, on average, a positive rate of increase, as suggested in recent macroscale studies of the species throughout its range (Defeo \& Cardoso 2002, 2004). This is also consistent with the universally accepted perception of dissipative beaches as self-sustaining or semi-closed ecosystems, where the beach itself and a surf zone that is extremely rich in surface phytoplankton provide high amounts of food (Defeo \& McLachlan 2005) for filter feeders such as Emerita brasiliensis. These high-quality habitats have a per capita availability of resources that is higher than in low-quality habitats (reflective beaches), which have been defined as interfaces with low productivity that is subsidized by organic inputs from the sea (McLachlan \& Brown 2006). It is worth noting that dissipative semi-closed ecosystems have a distinctive water circulation pattern and stable oceanographic structures that provide the basis for phytoplankton (McLachlan \& Brown 2006) and larval (Efford 1970, Defeo 1996) retention areas within the surf zone, suggesting that mole crab larvae have a much greater probability of settling in the vicinity of the beach from which they came. This could be important for marine invertebrates with feeding larvae (as E. brasiliensis), where local food availability in the plankton could affect the benefits of delaying metamorphosis in the absence of settlement cues (Elkin \& Marshall 2007).

In open marine systems such as sandy beaches, a sink habitat has been defined as one that receives more settlers than it generates (i.e. pre-settlement mortality combined with post-settlement survival and reproduction leads to $<1$ settler being exported to surrounding subpopulations for each original settler into the local site: sensu Chockley et al. 2008). Identifying sources and sinks in sandy beaches thus requires quantification of the relative importance of presettlement vs. post-settlement processes. In this paper, we have focused on several benthic demographic properties of the mole crab in order to provide insights on source-sink dynamics. We are aware, however, that connectivity patterns between sandy beach populations that are linked by larval dispersal are still an unexplored field of research, and that the mechanisms influencing larval distribution are poorly understood (Defeo \& McLachlan 2005). Although it has been suggested that several mole crab species in local open sandy coasts are self-sustaining (Efford 1970), a planktonic larval stage suggests dispersal potential (Sorte et al. 2001, Yannicelli et al. 2006, Diehl et al. 2007) and a variable degree of gene flow among populations. In this vein, oceanographic (nearshore hydrodynamics), atmospheric (wind stress) and topographic (headlands) effects on larval dispersal and settlement processes have yet to be elucidated. Moreover, overcompensatory adult-larval relationships (i.e. an inhibition of recruitment at high adult densities) through passive filtering of settling larvae by adults can also explain settlement inhibition by benthic sandy beach suspension feeders (Defeo 1996). Other compensatory mechanisms (e.g. density-dependent fecundity, growth and survival rates) may also account for the space-time recruitment variability (Lima et al. 2000).

In summary, by combining estimates of abundance (total and by population component) with size structure analysis, we showed that (1) large-scale spatial variations in morphodynamic and estuarine gradients can affect mole crab demography: population attrib- 
utes are affected locally by beach morphodynamics, following the main predictions of the $\mathrm{HHH}$, and regionally by the estuarine gradient caused by the Rio de la Plata discharge; and (2) reflective and estuarine beaches could be defined as sink habitats, whereas dissipative beaches could be considered as source habitats. It is hypothesized that sink habitats can persist locally by continued between-beach connectivity through larval dispersal, and immigration from dissipative nearby beaches. Studies on connectivity issues and long-term variations in demographic processes as well as genetic analyses are needed to gain a deeper understanding of source-sink dynamics in sandy beaches.

Acknowledgements. This paper is part of the PhD thesis of E.C. We thank the 'Benthic Ecology Group' of UNDECIMAR for field and laboratory assistance. Four referees provided useful suggestions that improved the paper. Financial support was provided by CONICYT (Project Nos. 1018 and 4034), PDT (Project S/C/OP/07/49), DINARA (UTF/URU/025/URU), ANII and PEDECIBA.

\section{LITERATURE CITED}

Caddy J, Defeo O (2003) Enhancing or restoring the productivity of natural populations of shellfish and other marine invertebrate resources. FAO Fish Tech Pap 448

Cardoso R, Veloso V (2003) Population dynamics and secondary production of the wedge clam Donax hanleyanus (Bivalvia: Donacidae) on a high-energy, subtropical beach of Brazil. Mar Biol 142:153-162

Cardoso R, Veloso V, Caetano H (2003) Life history of Emerita brasiliensis (Decapoda: Hippidae) on two beaches with different morphodynamic characteristics. J Coast Res Spec Issue 35:392-401

Celentano E, Defeo O (2006) Habitat harshness and morphodynamics: life history traits of the mole crab Emerita brasiliensis in Uruguayan sandy beaches. Mar Biol 149: 1453-1461

Chambers J, Hastie T (1992) Statistical models in S. Wadsworth \& Brooks/Cole Advanced Books and Software, Pacific Grove, CA

Chockley BR, St. Mary CM, Osenberg CW (2008) Population sinks in the Upper Florida Keys: the importance of demographic variation in population dynamics of the marine shrimp Stenopus hispidus. Mar Ecol Prog Ser 360:135-145

Contreras H, Jaramillo E, Duarte C, McLachlan A (2003) Population abundances, growth and natural mortality of the crustacean macroinfauna at two sand beach morphodynamic types in southern Chile. Rev Chil Hist Nat 76 : 543-561

de la Huz R, Lastra M, López J (2002) The influence of sediment grain size on burrowing, growth and metabolism of Donax trunculus L. (Bivalvia: Donacidae). J Sea Res 47: 85-95

Defeo O (1996) Recruitment variability in sandy beach macroinfauna: much to learn yet. Rev Chil Hist Nat 69: $615-630$

> Defeo O, Cardoso R (2002) Macroecology of population dynamics and life history traits of the mole crab Emerita brasiliensis in Atlantic sandy beaches of South America.
Mar Ecol Prog Ser 239:169-179

> Defeo O, Cardoso R (2004) Latitudinal patterns in abundance and life-history traits of the mole crab Emerita brasiliensis on South American sandy beaches. Divers Distrib 10: 89-98

Defeo O, de Álava A (1995) Effects of human activities on long-term trends in sandy beach populations: the wedge clam Donax hanleyanus in Uruguay. Mar Ecol Prog Ser 123:73-82

Defeo O, McLachlan A (2005) Patterns, processes and regulatory mechanisms in sandy beach macrofauna: a multiscale analysis. Mar Ecol Prog Ser 295:1-20

Defeo O, Jaramillo E, Lyonnet A (1992) Community structure and intertidal zonation of the macroinfauna in the Atlantic coast of Uruguay. J Coast Res 8:830-839

> Defeo O, Gómez J, Lercari D (2001) Testing the swash exclusion hypothesis in sandy beach populations: the mole crab Emerita brasiliensis in Uruguay. Mar Ecol Prog Ser 212: $159-170$

Defeo O, Lercari D, Gómez J (2003) The role of morphodynamics in structuring sandy beach populations and communities: what should be expected? J Coast Res Spec Issue 35:352-362

> Defeo O, McLachlan A, Schoeman D, Schlacher T and others (2009) Threats to sandy beach ecosystems: a review. Estuar Coast Shelf Sci 81:1-12

> Delgado E, Defeo O (2006) A complex sexual cycle in sandy beaches: the reproductive strategy of Emerita brasiliensis (Decapoda: Anomura). J Mar Biol Assoc UK 86:361-368

- Delgado E, Defeo O (2008) Reproductive plasticity in mole crabs, Emerita brasiliensis, in sandy beaches with contrasting morphodynamics. Mar Biol 153:1065-1074

- Diehl J, Toonen R, Botsford L (2007) Spatial variability of recruitment in the sand crab Emerita analoga throughout California in relation to wind-driven currents. Mar Ecol Prog Ser 350:1-17

Dugan J, Hubbard D, Page H (1995) Scaling population density to body size: tests in two soft sediment intertidal communities. J Coast Res 11:849-857

Efford I (1970) Recruitment to sedentary marine populations as exemplified by the sand crab, Emerita analoga (Decapoda, Hippidae). Crustaceana 18:293-308

Elkin C, Marshall DJ (2007) Desperate larvae: influence of deferred costs and habitat requirements on habitat selection. Mar Ecol Prog Ser 335:143-153

Folk R (1974) Petrology of sedimentary rocks. Hemphill Publishing, Austin, TX

Gibbs RJ, Matthews MD, Link DA (1971) The relationship between sphere size and settling velocity. J Sediment Petrol 41:7-18

Guerrero R, Acha E, Framinian M, Lasta C (1997) Physical oceanography of the Rio de la Plata Estuary, Argentina. Cont Shelf Res 17: 727-742

> Guisan A, Thuiller W (2005) Predicting species distribution: offering more than simple habitat models. Ecol Lett 8: 993-1009

Hastie T, Tibshirani R (1990) Generalized additive models. Chapman \& Hall, London

Herrmann M (2009) Population dynamics of the surf clams Donax hanleyanus and Mesodesma mactroides from open-Atlantic beaches off Argentina. Rep Pol Mar Res 585:235 p

Jaramillo E, Duarte C, Contreras H (2000) Sandy beach macroinfauna from the coast of Ancud, Isla de Chiloe, Southern Chile. Rev Chil Hist Nat 73:771-786

- Lercari D, Defeo O (1999) Effects of freshwater discharge in sandy beach populations: the mole crab Emerita brasilien- 
sis in Uruguay. Estuar Coast Shelf Sci 49:457-468

Lercari D, Defeo O (2006) Large-scale diversity and abundance trends in sandy beach macrofauna along full gradients of salinity and morphodynamics. Estuar Coast Shelf Sci 68:27-35

Lima M, Brazeiro A, Defeo O (2000) Population dynamics of the yellow clam Mesodesma mactroides: recruitment variability, density-dependence and stochastic processes. Mar Ecol Prog Ser 207:97-108

McLachlan A (1990) Dissipative beaches and macrofauna communities on exposed intertidal sands. J Coast Res 6: $57-71$

McLachlan A, Brown AC (2006) The ecology of sandy shores, 2nd edn. Elsevier, Amsterdam

McLachlan A, Dorvlo A (2005) Global patterns in sandy macrobenthic communities. J Coast Res 21:674-687

McLachlan A, Jaramillo E, Donn TE, Wessels F (1993) Sand beach macrofauna communities: a geographical comparison. J Coast Res Spec Issue 15:27-38

McLachlan A, Jaramillo E, Defeo O, Dugan J, de Ruyck A, Coetzee P (1995) Adaptations of bivalves to different beach types. J Exp Mar Biol Ecol 187:147-160

Möller OO Jr, Piola AR, Freitas AC, Campos EJD (2008) The effects of river discharge and seasonal winds on the shelf off southeastern South America. Cont Shelf Res 28: 1607-1624

Montgomery DC, Peck EA (1992) Introduction to linear regression analysis, 2nd edn. John Wiley \& Sons, New York

Murray-Jones S, Ayre D (1997) High levels of gene flow in the surf bivalve Donax deltoides (Bivalvia: Donacidae) on the east coast of Australia. Mar Biol 128:83-89

Nel P, McLachlan A, Winter D (2001) The effect of grain size on the burrowing of two Donax species. J Exp Mar Biol Ecol 265:219-238

Ortega L, Martínez A (2007) Multiannual and seasonal variability of water masses and fronts over the Uruguayan shelf. J Coast Res 23:618-629

Otegui ACP, Soares-Gomes A (2007) Desenvolvimento 'in vitro' de larvas e juvenis de Emerita brasiliensis Schmitt

Editorial responsibility: Hans Heinrich Janssen, Oldendorf/Luhe, Germany
(Crustacea, Decapoda, Hippidae) sob diferentes condições de temperatura, salinidade e regime alimentar. Rev Brasil Zool 24:277-282

Rodil I, Lastra M (2004) Environmental factors affecting benthic macrofauna along a gradient of intermediate sandy beaches in northern Spain. Estuar Coast Shelf Sci 61: $37-44$

Schoeman DS, Richardson AJ (2002) Investigating biotic and abiotic factors affecting the recruitment of an intertidal clam on an exposed sandy beach using a generalized additive model. J Exp Mar Biol Ecol 276:67-81

Simionato C, Berasategui A, Meccia V, Acha M, Mianzan H (2008) Short time-scale wind forced variability in the Río de la Plata Estuary and its role on ichthyoplankton retention. Estuar Coast Shelf Sci 76:211-226

Soares A (2003) Sandy beach morphodynamics and macrobenthic communities in temperate, subtropical and tropical regions - a macroecological approach. PhD thesis, University of Port Elizabeth

Sorte C, Peterson W, Morgan C, Emmett R (2001) Larval dynamics of the sand crab, Emerita analoga, off the central Oregon coast during a strong El Niño period. J Plankton Res 23:939-944

Subramoniam T, Gunamalai V (2003) Breeding biology of the intertidal sand crab, Emerita (Decapoda: Anomura). Adv Mar Biol 46:91-182

Thompson GA, Sánchez De Bock M (2009) Influence of beach morphodynamics on the bivalve Donax hanleyanus and Mesodesma mactroides populations in Argentina. PSZN I: Mar Ecol 30:198-211

Veloso V, Valentin J (1993) Larval distribution and seasonal abundance of Emerita brasiliensis Schmitt, 1983 (Decapoda: Hippidae) in southern Brazil. Rev Bras Biol 51: 131-141

Wood S (2006) Generalized additive models: an introduction with R. Chapman \& Hall, London

Yannicelli B, Castro RL, Schneider W, Sobarzo M (2006) Crustacean larvae distribution in the coastal upwelling zone off Central Chile. Mar Ecol Prog Ser 319:175-189

Submitted: May 5, 2009; Accepted: September 28, 2009

Proofs received from author(s): December 16, 2009 